\title{
Pelatihan Kewirausahaan via Daring di Unit Produksi SMKN 3 Tabanan
}

\author{
${ }^{1}$ I Gusti Ngurah Satria Wijaya, ${ }^{2}$ I Komang Budi Mas Aryawan, ${ }^{3}$ Ketut Gus Oka \\ Ciptahadi, ${ }^{4}$ Putu Krisna Yoga Astra, ${ }^{5}$ Ni Gusti Ayu Agung Ulan Darmayanti \\ ITB Stikom Bali \\ *Email: ngurah_satria@stikom-bali.ac.id
}

\begin{abstract}
RINGKASAN
Unit produksi merupakan tempat bagi setiap siswa di SMKN 3 Tabanan untuk menghasilkan suatu produk atau jasa pelayanan dan mempromosikan hasil produksi barang dan jasa kepada konsumen umum. Proses produksi dari produk dan jasa sudah berlangsung dengan baik, namun mitra belum pernah mendapatkan pelatihan tentang kewirausahaan dari pihak luar yang meliputi pembentukan calon wirausahaan muda dan perbaikan usaha dari berbagai segi komponen untuk membentuk usaha. Berdasarkan permasalahan tersebut, melalui pengabdian ini, mempunyai tujuan secara khusus, untuk peningkatan kemampuan dan kapasitas dari siswa yang tergabung dalam unit produksi agar dapat bersaing dalam dunia kerja maupun mampu berwirausaha yang baik. Metode yang digunakan adalah memberikan pelatihan kewirausahaan secara daring melalui aplikasi whatsapp baik dengan grup whatsapp maupun video call dikarenakan adanya pandemi virus corona covid 19 untuk mengharuskan melakukan social distancing dan physical distancing. Hasil evaluasi kegiatan pengabdian berupa kuisoner yang dijawab oleh keseluruhan peserta pelatihan kewirausahaan adalah 100 persen peserta merasa senang/puas dalam mengikuti pelatihan ini dengan hasil output tambahan berupa proposal bisnis mini.
\end{abstract}

Kata kunci : pelatihan, kewirausahaan, daring.

\section{SUMMARY}

The production unit is a place for every student in SMKN 3 Tabanan to produce a product or service and promote the production of goods and services to the general consumer. The production process of products and services has been going well, but partners have never received training on entrepreneurship from outsiders which includes the formation of young entrepreneurial candidates and business improvement in various aspects of components to form a business. Based on these problems, through this dedication, has a specific goal, to increase the ability and capacity of students who are members of the production unit in order to compete in the world of work and be able to be a good entrepreneur. The method used is to provide online entrepreneurship training through the whatsapp application both with the whatsapp group and video call due to the corona covid 19 virus pandemic to require social distancing and physical distancing. The results of the evaluation of community service activities in the form of questionnaires answered by all participants in entrepreneurship training are 100 percent of participants feeling happy / satisfied in participating in this training with the results of additional output in the form of a mini business proposal.

Key words: training, entrepreneurship, online 


\section{PENDAHULUAN}

Sekolah Menengah Kejuruan Negeri 3 Tabanan (SMKN 3 Tabanan) yang terletak di Kecamatan Selemadeg Timur Kabupaten Tabanan merupakan sekolah menengah kejuruan yang mempunyai lima program studi yaitu Teknik Otomotif, Teknik Elektronika, Teknik Komputer dan Informatika, Teknik Bangunan serta Jasa Boga. SMKN 3 Tabanan mempunyai visi yakni mewujudkan sekolah yang dapat menciptakan sumber daya manusia (SDM) yang terampil, mandiri, produktif dan profesional di bidangnya dan salah satu misi yaitu mengantarkan lulusan untuk siap bekerja, membuka usaha dan atau melanjutkan pendidikan ke jenjang yang lebih tinggi (data diambil dari http://smkn3tabanan.sch.id/sekolah-profil/)

Untuk melaksanakan visi dan misi sekolah, terbentuklah struktur kerja yang dinamakan unit produksi. Unit produksi merupakan wadah bagi setiap siswa di SMKN 3 Tabanan untuk membuat suatu produk atau jasa pelayanan dan memasarkan hasil produksi barang dan jasa kepada masyarakat umum, sehingga dapat dikatakan bentuk unit produksi berupa badan usaha milik sekolah serta mitra dapat dikelompokkan ke calon ekonomi produktif. Produk atau jasa yang dihasilkan di unit produksi ini adalah jasa perbaikan bengkel motor dan cuci motor, jasa perbaikan alat-alat elektronika, jasa perbaikan komputer dan pemasangan jaringan gedung atau kantor, jasa produk desain rumah, dan makanan dan kue-kue tergantung dari masing-masing program studi.

Proses produksi dari unit produksi ini sudah berjalan pada saat ini. Terlebih dengan sudah diberikan bantuan berupa media promosi e commerce berupa website, pelatihan admin website dan pelatihan media pemasaran sebelumnya oleh tim pengabdian ITB STIKOM Bali dengan hasil grafik yang menunjukkan peningkatan (Wijaya et al, 2020). Kendala yang masih ada saat ini adalah belum adanya pelatihan tentang kewirausahaaan dari pihak luar, dimana selama ini masih dikelola oleh internal sekolah..

Berikut adalah analisis situasi dalam bentuk tabel di bawah ini :

Tabel 1. Analisis Situasi

\begin{tabular}{|l|l|l|l|}
\hline No & Bidang & Permasalahan & Solusi \\
\hline 1 & $\begin{array}{l}\text { Manaje } \\
\text { men }\end{array}$ & $\begin{array}{l}\text { Belum pernah } \\
\text { mendapatkan } \\
\text { pelatihan } \\
\text { kewirausahaan } \\
\text { untuk siswa- } \\
\text { siswa SMK }\end{array}$ & $\begin{array}{l}\text { Pelatihan } \\
\text { Kewiraus } \\
\text { ahaan }\end{array}$ \\
\hline
\end{tabular}

Berikut adalah foto dokumentasi hasil observasi awal di SMKN 3 Tabanan seperti gambar dibawah ini

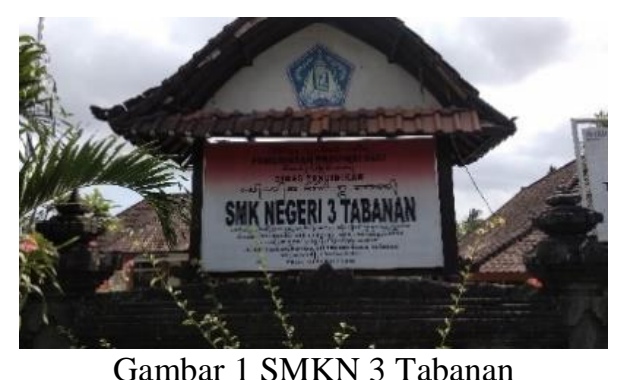

Gambar 1 SMKN 3 Tabanan

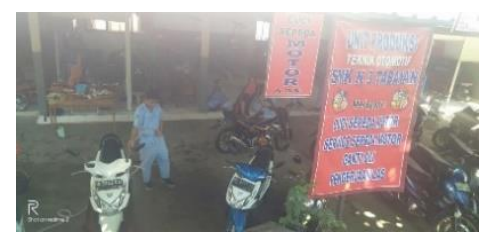

Gambar 2 Unit Produksi SMKN 3 Tabanan

Tujuan dari kegiatan pengabdian ini adalah secara khusus, untuk peningkatan kemampuan dan kapasitas dari siswa yang tergabung dalam unit produksi agar dapat bersaing dalam dunia kerja maupun mampu berwirausaha yang baik. Pelatihan kewirausahaan ini sebagai bentuk inovasi untuk meningkatkan jumlah wirausaha yang baru (As'ad, 2019).

Secara umum dari lingkup unit produksi, untuk perbaikan usaha unit produksi dari berbagai segi komponen dalam bidang manajemen. 


\section{RUMUSAN MASALAH}

Berdasarkan hasil analisa pada analisis situasi, dapat dirumuskan permasalahan yang dihadapi mitra, yaitu mitra belum pernah mendapatkan pelatihan tentang kewirausahaan dari pihak luar yang meliputi pembentukan calon wirausahaan muda dan perbaikan usaha dari berbagai segi komponen untuk membentuk usaha.

\section{METODE}

Metode yang digunakan dalam pengabdian ini seperti terlihat pada gambar 4 adalah sosialisasi kegiatan pengabdian, memberikan pelatihan tentang kewirausahaan untuk peningkatan kemampuan dan kapasitas dari siswa dalam unit produksi agar mampu bersaing dalam dunia kerja maupun mampu berwirausaha yang baik dan secara umum, untuk perbaikan usaha unit produksi dari berbagai segi komponen dalam bidang manajemen. Evaluasi kegiatan dilakukan untuk mengetahui keberhasilan dari kegiatan ini. Ketiga kegiatan diatas dilakukan secara daring melalui aplikasi whatsapp baik melalui grup whatsapp maupun video call dikarenakan adanya pandemi virus corona covid 19 untuk mengharuskan melakukan social distancing dan physical distancing.

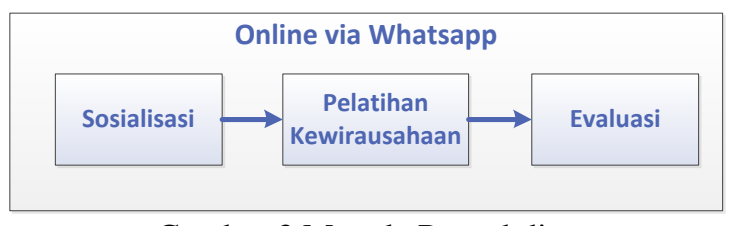

Gambar 3 Metode Pengabdian

\section{PEMBAHASAN}

Kegiatan pengabdian ini berupa kegiatan sosialisasi ke tempat mitra, pelatihan kewirausahaan, dan evaluasi kegiatan sesuai dengan jadwal pelaksanaan pengabdian dibawah ini.

Tabel 2 Jadwal Pelaksanaan Pengabdian

\begin{tabular}{|l|l|l|l|}
\hline No & Tanggal & Kegiatan & Uraian \\
\hline 1 & $\begin{array}{l}\text { 16 April } \\
2020\end{array}$ & Sosialisasi 1 & $\begin{array}{l}\text { Koordinasi dengan } \\
\text { Wakasek via chat } \\
\text { Whatsapp }\end{array}$ \\
\hline
\end{tabular}

\begin{tabular}{|l|l|l|l|}
\hline 2 & $\begin{array}{l}21 \text { April } \\
2020\end{array}$ & Sosialisasi 2 & $\begin{array}{l}\text { Koordinasi dengan } \\
\text { Wakasek via chat } \\
\text { Whatsapp }\end{array}$ \\
\hline 3 & $\begin{array}{l}23 \text { April } \\
2020\end{array}$ & Sosialisasi 3 & $\begin{array}{l}\text { Koordinasi dengan } \\
\text { Wakasek via chat } \\
\text { Whatsapp }\end{array}$ \\
\hline 4 & $\begin{array}{l}23 \text { April } \\
2020\end{array}$ & $\begin{array}{l}\text { Pelatihan } \\
\text { Kewirausaha } \\
\text { an }\end{array}$ & $\begin{array}{l}\text { Membagikan materi } \\
\text { pelatihan via WA dan } \\
\text { google drive }\end{array}$ \\
\hline 5 & $\begin{array}{l}24 \text { April } \\
2020\end{array}$ & $\begin{array}{l}\text { Pelatihan } \\
\text { Kewirausaha } \\
\text { an }\end{array}$ & $\begin{array}{l}\text { Sesi Tanya Jawab via } \\
\text { grup WA dan Video } \\
\text { Call }\end{array}$ \\
\hline 6 & 27 April & $\begin{array}{l}\text { Evaluasi } \\
\text { Kegiatan }\end{array}$ & $\begin{array}{l}\text { Memonitoring dan } \\
\text { mengevaluasi } \\
\text { kegiatan serta batas } \\
\text { akhir pengumpulan } \\
\text { tugas proposal bisnis }\end{array}$ \\
\hline
\end{tabular}

Adapun rincian kegiatan pengabdian adalah seperti dibawah ini:

\section{Sosialisasi ke Unit Produksi SMKN 3 Tabanan}

Sosialisasi pertama dilakukan pada tanggal 16 April 2020 pukul 07.30 WITA dengan berkoordinasi dengan Wakasek Bidang Sarana dan Prasarana sekaligus Ketua Unit Produksi melalui chat dengan whatsapp. Kegiatan ini dilakukan untuk menyampaikan informasi-informasi mengenai latar belakang, target, sasaran dan tujuan kegiatan berupa pelatihan kewirausahaan serta membahas mengenai jumlah peserta, waktu, sarana prasarana pelatihan yang dilakukan via daring. Sosialisasi kedua dilakukan pada tanggal 21 April 2020 pukul 07.20 untuk membicarakan jumlah peserta yang nantinya akan dimasukkan ke grup whatsapp untuk pelatihan. Terakhir sosialisasi atau koordinasi ketiga dilakukan pada tanggal 23 April 2020 (H1) pukul 07.11 untuk membicarakan tentang metode pemberian materi melalui daring.

\section{Pelatihan kewirausahaan}

Pelatihan kewirausahaan ini hanya diikuti oleh 10 peserta dengan kriteria peserta pelatihan ini adalah umur 16 tahun keatas, jenis kelamin pria dan wanita, 
pendidikan minimal lulusan SMP, status peserta adalah siswa SMK yang tergabung dalam Unit Produksi. Peserta dimasukan kedalam sebuah grup whatsapp dengan nama Pelatihan Kewirausahaan. Kegiatan yang dilakukan dalam pelatihan ini yaitu pertama membagikan materi pelatihan berupa powerpoint, MS word berupa handout materi melalui grup whatsapp dan video tutorial dari materi powerpoint tersebut terlebih dahulu melalui google drive dan kemudian peserta dapat mendownload link materi lewat google drive tersebut untuk dipelajari dan dipahami. Intisari dari materi pelatihan kewirausahaan ini adalah pengertian dasar kewirausahaan, karakteristik seorang wirausaha, jenis-jenis entrepreneurship, berpikir kreatif, inovasi, strategi pemasaran, dan pengelolaan keuangan (Kasali, 2010). Kegiatan ini dilakukan pada tanggal 23 April 2020 pada pukul 16.36 WITA. Kedua, sesi tanya jawab dilakukan melalui chat di grup whatsapp maupun melalui tanya jawab dengan videocall whatsapp. Kegiatan ini dilakukan pada tanggal 24 April 2020 pukul 11.2713.09 WITA. Sebagai tambahan untuk sarana evaluasi peserta diberikan tugas berkelompok untuk membuat proposal bisnis mini dimana satu kelompok terdiri dari 2-3 orang peserta.

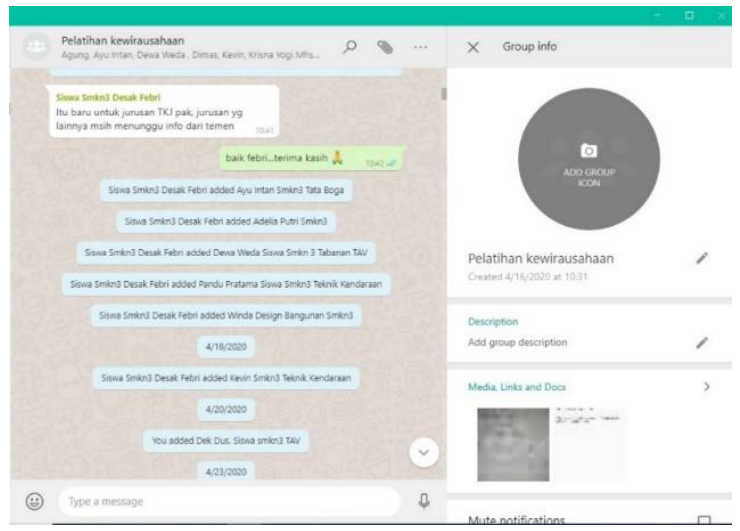

Gambar 4 Screenshoot Grup Whatsapp

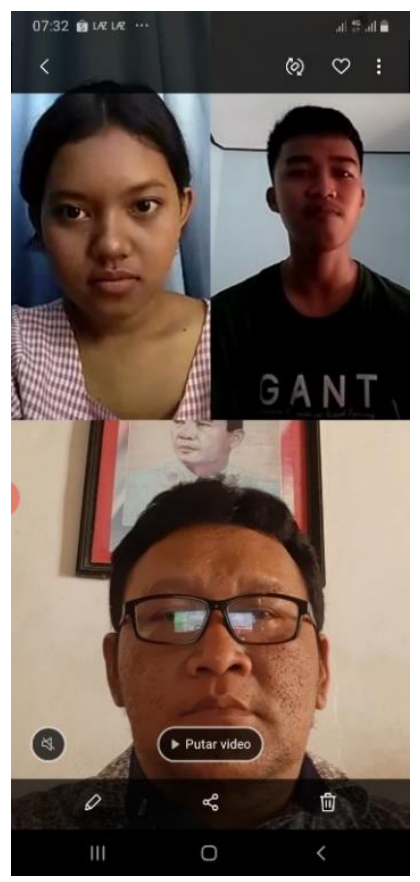

Gambar 5 Screenshoot Video Call via Whatsapp

\section{Evaluasi Kegiatan}

Hasil evaluasi berupa kuisoner yang dijawab oleh keseluruhan peserta pelatihan kewirausahaan adalah 100 persen peserta merasa senang/puas dalam mengikuti kegiatan sehingga peserta tidak mengalami kesulitan dalam memahami intisari dari materi pelatihan kewirausahaan berupa pengertian dasar kewirausahaan, karakteristik seorang wirausaha, jenis-jenis entrepreneurship, berpikir kreatif, inovasi, strategi pemasaran, dan pengelolaan keuangan. Penggunaan media pelatihan berupa powerpoint yang menarik dan tidak membosankan serta penggunaan video tutorial materi pelatihan tersebut juga mendorong peserta untuk lebih mudah dalam memahami materi pelatihan kewirausahaan. Berikut adalah contoh secara garis besar materi yang disajikan dalam bentuk powerpoint seperti gambar dibawah ini. 


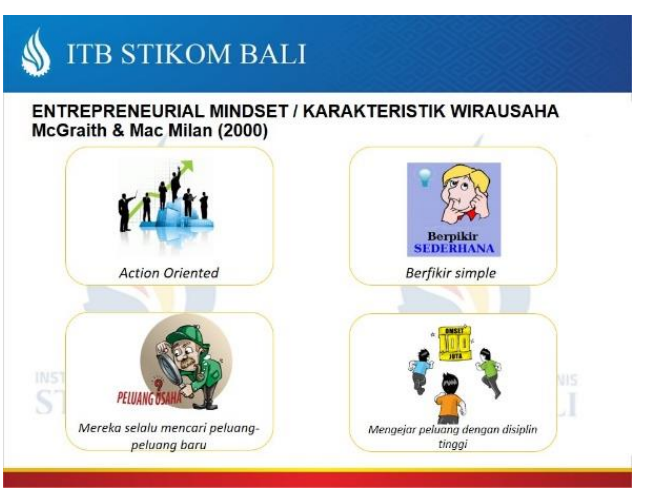

Gambar 6 Materi Pelatihan Kewirausahaan

\section{ITB STIKOM BALI}

Pilihan Entrepreneurship
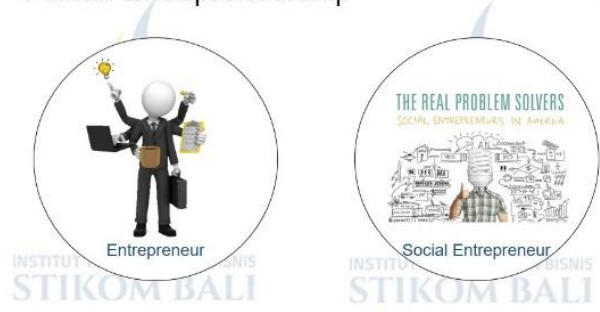

Gambar 7 Materi Pelatihan Kewirausahaan

\section{ITB STIKOM BALI}

\section{BERPIKIR KREATIF}

Kreativitas Sebagai Modal Penting Wirausaha

Kreativitas merupakan kemampuan seseorang untuk dapat memikirkan dan mengembangkan ide-ide baru, cara-cara baru dalam melihat masalah peluang. sehingga muncul solusi kreatif
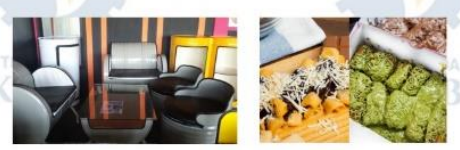

Gambar 8 Materi Pelatihan Kewirausahaan

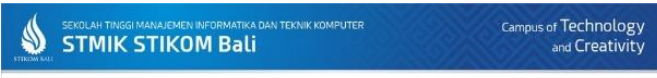
Inovasi

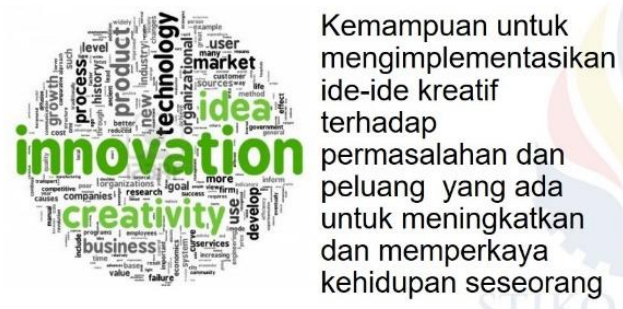

Gambar 9 Materi Pelatihan Kewirausahaan

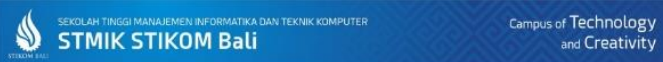

Strategi Pemasaran

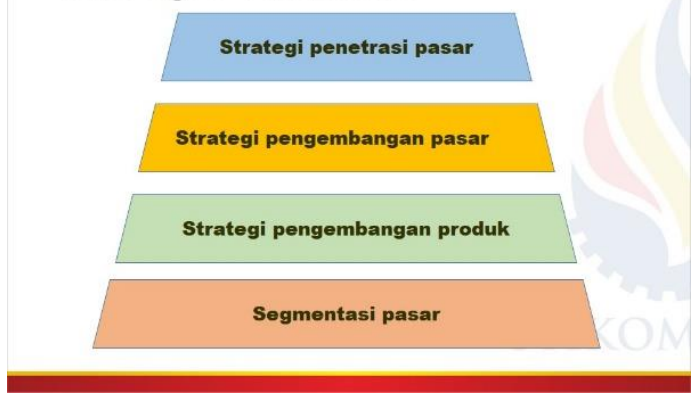

Gambar 10 Materi Pelatihan Kewirausahaan

Peserta juga secara aktif mengajukan pertanyaan tentang kewirausahaan yaitu sebanyak $60 \%$ dari keseluruhan peserta, seperti terlihat pada gambar 5 diatas.

Sebagai hasil evaluasi kegiatan tambahan berupa tugas berkelompok untuk membuat proposal bisnis mini adalah sebagai berikut:

Tabel 3 Penilaian Proposal Bisnis Mini

\begin{tabular}{|l|r|r|r|r|}
\hline \multirow{2}{*}{ Kelompok } & \multicolumn{4}{|c|}{ Nilai } \\
\cline { 2 - 5 } & Juri 1 & Juri 2 & Juri 3 & $\begin{array}{c}\text { Nilai } \\
\text { Total }\end{array}$ \\
\hline $\begin{array}{l}\text { Kelompok } \\
\text { Winda dan } \\
\text { Febri }\end{array}$ & 75.00 & 75.00 & 75.00 & 75 \\
\hline $\begin{array}{l}\text { Kelompok } \\
\text { Yudi dan } \\
\text { Ayu Risna }\end{array}$ & 78.00 & 81.67 & 81.67 & 80.44 \\
\hline $\begin{array}{l}\text { Kelompok } \\
\text { Kevin \& } \\
\text { Ayu intan }\end{array}$ & 80.00 & 83.33 & 81.67 & 81.67 \\
\hline
\end{tabular}

Dengan terlaksananya kegiatan pelatihan kewirausahaan telah memberikan dampak positif terhadap peningkatan kemampuan dan kapasitas dari siswa yang tergabung dalam unit produksi agar dapat bersaing dalam dunia kerja maupun mampu berwirausaha yang baik dan secara umum, untuk perbaikan usaha unit produksi dari berbagai segi komponen dalam bidang manajemen, seperti yang ditunjukkan pada hasil kegiatan pengabdian tahap pertama sebelumnya. 


\section{SIMPULAN}

Proses

kegiatan pelatihan

kewirausahaan secara daring berjalan dengan baik. Hasil evaluasi berupa kuisoner yang dijawab oleh keseluruhan peserta pelatihan kewirausahaan adalah 100 persen peserta merasa senang/puas dalam mengikuti pelatihan ini dengan hasil output tambahan berupa proposal bisnis mini.

\section{UCAPAN TERIMA KASIH}

Penulis menyadari tanpa adanya bantuan dari berbagai pihak, maka penulis tidak dapat menyelesaikan pengabdian masyarakat ini dengan baik, untuk itu penulis ingin mengucapkan terimakasih kepada Rektor ITB STIKOM Bali yang telah memberikan kesempatan dan sumber dana untuk melakukan pengabdian masyarakat. Ucapan terima kasih selanjutnya kepada Kepala Pusat Pengabdian Masyarakat ITB STIKOM Bali yang telah membantu dan memfasilitasi hingga terselesaikannya pengabdian masyarakat ini. Terima kasih juga disampaikan kepada pengelola unit produksi SMKN 3 Tabanan yang telah memberikan izin serta menyambut kegiatan kami dengan baik. Kami selaku pengusul mengucapkan terimakasih yang sebesar-besarnya. Semoga kegiatan ini bisa bermanfaat untuk kemajuan unit produksi.

\section{DAFTAR PUSTAKA}

SMKN 3 Tabanan. 2012. Profil Sekolah, Sistem Informasi Aplikasi Pendidikan SMKN 3 Tabanan website : http://smkn3tabanan.sch.id/sekolahprofil//

As'ad, A., Syahnur, A., \& Arumbarkah, M. 2019. Pelatihan Motivasi dan Kewirausahaan bagi Warga Desa Sanrobone Kabupaten Takalar. Jurnal Pengabdian Bina Ukhuwah, 1(1), 8-15 Kasali, R., dkk, 2010, Modul Kewirausahaan untuk Program
Strata 1. Jakarta: Hikmah (PT Mizan Publika),

Wijaya, I.G.N.S., Aryawan, I.K.B.M., Ciptahadi, K.G.O., Astra P.K.Y., Darmayanti, N.G.A.A.U. 2020. Pelatihan Admin Website dan Pemasaran Unit Produksi SMKN 3 Tabanan, Widyabhakti Jurnal Ilmiah Populer, 2(2), 76-81 